\title{
PHILOLOGY
}

\section{COMPARATIVE ANALYSIS OF SOME LYRIC AND EPIC GENRES IN AZERBAIJANI AND ENGLISH CHILDREN'S FOLKLORE}

\author{
Nigar Aghayeva \\ Azerbaijan National Academy of Sciences Folklore Institute, Baku, Azerbaijan \\ https://orcid.org/0000-0002-9547-3796
}

DOI: https://doi.org/10.31435/rsglobal_wos/28022020/6912

\section{ARTICLE INFO}

Received: 11 December 2019

Accepted: 16 February 2020

Published: 28 February 2020

\section{KEYWORDS}

Children's folklore,

lullaby,

riddle,

tongue twister,

nursery rhyme.

\begin{abstract}
Children's folklore genres play a very important role in children's development. Article is devoted to the comparative study of some lyric and epic genre features of Azerbaijani and English children's folklore. Children folklore has a lot of common peculiarities. But there are also some differences. In this regard, the subject of the research is fundamental and comparative typological analysis of the lyric and epic genres of Azerbaijani and English children's folklore were involved to the research. Article provides a comparative analysis of both Azerbaijani and English lullabies, riddles, tongue twister, and children's songs. Thus, the similarity of folklore genres in the study is linked to the closeness of human thought and its relation to reality. The similar life conditions of Azerbaijani and English peoples and the stereotypes of behavior formed according to these situations, oral traditions, especially comparisons of children's folklore texts revealed parallels in terms of information. Similarities in connection with life conditions are clearly observed in many children's folklore genres, as well as in some lyric and epic genres.
\end{abstract}

Citation: Nigar Aghayeva. (2020) Comparative Analysis of Some Lyric and Epic Genres in Azerbaijani and English Children's Folklore. International Academy Journal Web of Scholar. 2(44). doi: 10.31435/rsglobal_wos/28022020/6912

Copyright: (C) 2020 Nigar Aghayeva. This is an open-access article distributed under the terms of the Creative Commons Attribution License (CC BY). The use, distribution or reproduction in other forums is permitted, provided the original author(s) or licensor are credited and that the original publication in this journal is cited, in accordance with accepted academic practice. No use, distribution or reproduction is permitted which does not comply with these terms.

Introduction. In both Azerbaijani and English folklore a special emphasis is placed on the upbringing of the younger generation. Children's folklore genres develop aesthetic feelings of children, nurture them in the spirit of the traditions of their people, and encourage them to love their country, their people and their language. Scientific and theoretical views of many researchers on the problems of children's folklore in Azerbaijani and English folklore have been analyzed. Using the method of comparative analysis, specifications and idea-artistic features of Azerbaijani and English children's folklore genres were explored.

Research results. Theme and plot similarity of the different genres of Azerbaijan and English children's folklore- lullabies-cradles, riddles and tongue-twisters is related to the fact that the life and lifestyle of children are the same for all peoples of the world.

Lullabies are one of the most popular genres in both Azerbaijan and English children's folklore. They are the songs that have been sung to put babies to the bed and to fondle them. An Azerbaijani mother says for her baby:

"Laylay dedim, yatasan, / Lay-lay my dear, sleep,

Q1z1l gülə batasan, / Fall into the roses

Q1zıl gülün içində/ Among the roses 
Şirin yuxu tapasan / Find a very sweet dream " [Children's folklore, 2007:10].

On the other hand, a woman in England also expresses her heartfelt feelings for her child:

"Day is done,

Gone the sun,

From the lake, from the hills, from the sky.

All is well, safely rest,

God is nigh..." [https://www.famlii.com/day-is-done-lullaby-lyrics/].

Prof. Shahin Khalilli, the researcher of Azerbaijan and English literary relations translated this lullaby into Azerbaijani as follows:

"Günüm bitdi,

Günəş batdı

Təpələrdən,

Göldən, göydən

No vardisa yuxuladi.

Pənahımız Allahadı" [Shahin Khalilli, 2002:42].

Despite the difference in content and form the sense of purity is felt within hemistich in both lullaby samples. The power of faith in religion and religious rituals is also manifested in rituals in English children's songs. Children who want to play in the yard sing the following songs to stop the rain:

Rain, rain, go away.

Come again another day;

Little Arthur wants to play" [The Nursery Rhymes of England, 1843:214].

We can observe the traces of the original belief in the call of sun (sun rise, sun rise, ride a bay horse), wind (Oh wind grandfather, wind grandfather) or in godu-godu ceremonial song in Azerbaijani folklore.

In both folklore samples the child calls the forces of nature, the sun, the wind, the rain, and says the magic witchcraft. In both Azerbaijan and English appeals, the child interacts with the forces of nature: he wants hot and endearment from the sun; He asks for strong rain or to stop the rain.

There are counting-out rhymes in the children's folklore of all nations. Counting-out rhymes taught to count from ancient times to the present day in Azerbaijan. The naming of each finger helps to keep and remember the numerical system well. Children remember and keep alive such countingout rhymes that bring comfort to their spirits.

Bura bir xərmənidi (Here was a threshing floor)

Bura bir quş qondu. (A bird sat here)

Biri vurdu, (The first hit)

Biri tutdu, (The second caught)

Biri pişirdi, (The third cooked)

Biri yedi, (The fourth ate)

Cöcülüyə qalmadı (The Fifth is nothing left) [Southern Azerbaijani folklore, 2015: 34].

The five fingers are the most basic, the palm of the hand is threshing-floor. The hunter is the thumb, index finger catches, the middle finger cooks, ring finger eats, but the pinky finger is still little. This is further proof of the aforementioned idea. Such counting-out rhymes are for young children.These counting-out rhymes help children learn how to count from one to five.

There are also songs with fingers that are intended for teaching purposes in English children's folklore. They are in short song form and performs with gestures. Counting-out rhymes can also be called a teaching game because they teach a child a lot of movement. When the mother sings a song, it remains in the child's mind and child combines every word and gesture. These rhymes are more interesting for younger children. They draw the kid's attention and soothe them. These rhymes can be considered a special entertainment of adults with kids. In this case, body movements of both sides are remarkable. This is an english finger-related counting-out rhyme called "Round and round the garden".

"Round about, round about,

here sits the hare,

In the comer of a cornfield

and that's just there, (close to thumb)

This httle dog found her, (fingers, starting with thumb)

This htde dog ran her.

This little dog caught her,

This httle dog ate her. 
And this little dog said, Give me a little bit please" [ Opie \& Opie, I. and P, 1966:199].

This rhyme is very similar to Azerbaijan's finger-related songs-counting-out rhymes. While saying these words, the two fingers passes through the child's palm and then as the "dog" pursues the "rabbit" two fingers (index and middle fingers) run from the boy's arm to the shoulder. While the rhymes are performed teaching activities are performed in both Azerbaijan and English children's folklore.

In these entertaining English songs, counting-out rhymes are also used when counting children's feet. While singing "This Little Pig" song narrator touches the child's fingers in a row and finally tickles

"This little piggy went to market,

This little piggy stayed home,

This little piggy had roast beef,

This little piggy had none,

And this little piggy cried "wee wee wee" all the way home"

[https://en.wikipedia.org/wiki/This_Little_Piggy].

Azerbaijani and English counting-out rhymes include simple jokes, funny motives, and hand gestures to provide a cheerful mood. Both people use calculation methods in these songs.They encourage a child to calculate without having to deal with abstract mathematical problems. These are the first steps towards abstract calculation.

"Ladybird! Ladybird! Fly Away Home" game song is associated with ancient customs and traditions in Azerbaijani folklore. It is loved and performed by children in different regions of Azerbaijan. In this game song (nursery rhyme) children carry the Ladybird in their hand and ask her to make their wishes come true. First, the children search for Ladybird in the grass and flowers, then catch and carry it in their hands, make different wishes and set the Ladybird free. The wishes expressed in this joyful song differ in some parts of Azerbaijan: "Fatmanənə, fatmanənə, sarısı sizin zəmiyə, yaş11 1 bizim zəmiyə" (Ladybird, Ladybird yellow to your, green is to our cornfield) [Azerbaijan Folk Literature, 2001:95].

The nursery rhyme singing by English peasants in the past "Ladybird! Ladybird! Fly Away Home" is one of the songs that children sing in modern times.

"Ladybird, ladybird fly away home,

Your house is on fire and your children are gone,

All except one, and her name is Ann,

And she hid under the baking pan" [https://en.wikipedia.org/wiki/Ladybird_Ladybird].

When the villagers burned the fields for the next planting, they shouted:

Ladybird, ladybird, fly away home,

Thy house is on fire, thy children all gone,

All but one, and her name is Ann,

And she crept under the pudding-pan [W.Gannon,1902:288].

Ladybird is a beneficial insect that eats harmful insects that destroy plants. Villagers want to reduce the number of vermin and save useful Ladybird. At the moment, when Ladybird settle on children they are singing this song as if they were performing an ancient ceremony.

Tongue-twisters play a special role in strengthening the child's mind and memory. Tongue-twisters are created both in prose and poetry, reflects all the tenderness of lively folk language and as well as shaping children's fluent speech and attention, entertain them and become a means of nurturing as a word game.

In English folklore, tongue-twisters are similar to Azerbaijan tongue-twisters in terms of many qualities. So "She sells sea-shells" is an example of formation a new tongue-twister by replacing words.

"She sells sea-shells on the sea-shore.

The shells she sells are sea-shells, I'm sure.

So if she sells sea-shells on the sea-shore

I'm sure the sells are sea-shore shells" [Tongue Twisters Limericks and Humorous Verse, 2000:2].

The riddles reveal many differences in history and ethnic relations. The ethnic peculiarity of riddles are expressed in the selection of subjects to be found (especially household items), in the nature and metaphorical structures of the characters. Sometimes we encounter riddles with the names of fruits, animals, birds, food and so on. that they have become famous only in Azerbaijan and are almost never seen in other nations, as well as in English, or, conversely, a number of British items, food, animals, and bird names are not mentioned in our riddles.

In English riddles, the motives of the riddles are in or near the villagers' home. Small worms, chickens, milk, eggs and also home appliances are typical and popular topics. But the choice here is 
still very limited. Although dogs and horses are often not the answer to the riddle, they are sometimes used in the sense of comparison. Cats and mice are not used in any of the above situations. In England, those who use riddles rarely use the names of wild animals. Storks, bears, foxes or wolves are rarely found in riddles.But these creatures are often used in folk tales. Fruits or vegetables such as carrots, onions, walnuts, blackberries and cherries can rarely be the subject of riddles.Apples and pears are completely unknown to riddles. Unlike the flowers, the thistle are the subject of riddles.

One of the famous English children's songs talk about the mysterious creature "Humpty Dumpty." This hero has also been a source of many problems for translators. This character is translated into Azerbaijani as Shaltay-Baltay. Humpty Dumpty is an ordinary chicken egg and the truth is that if it breaks no force can combine it again. The description of things here is quite different.

"Humpty Dumpty sat on a wall,

Humpty Dumpty had a great fall;

All the King's horses

And all the King's men,

Couldn't put Humpty together again" [https://en.wikipedia.org/wiki/Humpty_Dumpty].

"Humpty Dumpty" in English means " fat and short". In illustrations, he is often described as an egg, but in some versions as a boy.The strangeness of the matter is that we have to guess the riddle itself from this description. This nursery rhyme was used as a riddle before.

It is clear from the text of egg related Azerbaijan children's riddle "O yanı qaya, Bu yanı qaya, İçində sarı maya" (The rock on that side, the rock on this side, yellow yeast inside) [Riddles, 2004:98] that all sides of the yellow yeast resembles a rock. If that rock- shell falls, it will not be possible to hold the yellow yeast together. Here, the expression "yellow yeast" plays the key to finding the riddle.

The riddles in Azerbaijani folklore are in the form of poetry and prose. Most of the riddles are expressed in verse form.Their 2, 3, 4 hemistiches patterns are more in number: Yaşıldı abası, Sarıdı libas1 (Badam) / Its aba (robe) is green, Clothing is yellow (Almond) [Riddles, 2004:57], Bizim evdə bir kişi var, Ağzında üç dişi var (Sacayaq) / There is a man in our house, There are three teeth in his mouth (Trivet) [Riddles, 2004:21].

Most of the riddles in the form of prose, begin with "O nədir ki?" / "What is it?" questions. Riddles in verse are more and different in structure. Some begin with the words, "Tap, tapmaca"/"Find, riddle", "Bizdə bir kişi var"/ "There is a man in our house".

In Azerbaijani and English folklore, they are based on a metaphorical description of something with metaphor. Some riddles are like counting-out words and this is also "lively math," a unique way of teaching the number.

Conclusions. Children's folklore is one of the distinct branches of folklore. It is possible to feel clearly the national spirit of the people, manner of life, cultural standards of language, manner of national thought in the genres of children's folklore. People's manner of life are coded in these genres for thousands of years. Azerbaijan, as well as English children's folklore is rich in terms of theme and motif. This is inevitable of differing these folklore genres from one another formed in the different places. But there are also aspects doing them close to one another like created by children or addressed to children.

The initial demonstration of literary thinking began from children's folklore. The parallels, as well as differences are available between Azerbaijani and English children's folklore genres. Children's nursery rhymes are very urgent issue in both English and Azerbaijan folklore. Regardless of their age, folklore affects a person's mental and psychological development. The power of religious belief shows itself on the basis of the rituals during the performance of Azerbaijani and English children's songs. Child also appeals to the power of nature in these rituals and tells the magic.

Riddle is one of the oldest genres of folklore. Riddles have been associated with mythological and animistic views during the first formation. Real life facts are also involved in the formation of the riddle genre. Riddles play a major role in the child's mental development. Riddles express all the characteristics of the surrounding world on symbols and signs. Riddles point surrounding objects, the world surrounding people using the poetic word code. The riddle genre is practically used to develop, improve, and agitate child's thought.

Tongue-twisters have particular importance in strengthening child's mind and memory. Creating an artificial speech habit of tongue-twisters is used to smooth a child's speech. The tonguetwisters reflect all the subtleties of the lively spoken language, along with forming children's fluent speech, attention, as well as entertaining them and as a word game becomes a means of education. 


\section{REFERENCES}

1. Azerbaijan Folk Literature (Anthology). In two books. The first book. Compiled by: Bahlul Abdulla. XXI House of New Publications, Baku, 2001, 376 pages.

2. Children's folklore / edited by R. Ismayilov. - Baku: The Golden Book, 2007, - 96 pages.

3. Faraway countries, native songs (Folklore samples, rhymes and poem). Baku, Yazichi, 1986, 197 pages.

4. Opie \& Opie, I. and P., The Oxford Dictionary of Nursery Rhymes. Oxford University Press, Ely House, London W., 1966, 544 pages.

5. Riddles. collected and compiled by N. Seyidov, Baku, "East-West", 2004, 208 pages.

6. Shahin Khalilli. Azerbaijani-English literary relations. "Azerbaijan National Encyclopedia" NPB, 2002, 216 pages.

7. Southern Azerbaijani folklore, V Book. Baki, Science and Education, 2015. 388 pages.

8. The Nursery Rhymes of England. By James Orchard Halliwell, London: John Russell Smith, 4, Old Compton Street, Soho Square. 1843, 323p.

9. Tongue Twisters Limericks and Humorous Verse. Selecded by Fiona Waters. Pearson Education Limited, England, 2000, 14 pages.

10. W.Gannon. Mother Goose's Rhymes Nursery Tales and Jingles. New York: Hurst And Company Publishers.1902, 418 pages.

11. https://en.wikipedia.org/wiki/Humpty_Dumpty

12. https://en.wikipedia.org/wiki/This_Little_Piggy

13. https://en.wikipedia.org/wiki/Ladybird_Ladybird

14. https://www.famlii.com/day-is-done-lullaby-lyrics/ 